\title{
Direito à Palavra: Interrogações Acerca Da Proposta Da Justiça Restaurativa
}

\author{
The Right To Say: Interrogations About \\ The Restorative Justice Proposal
}

Derecho A La Palabra: Dudas Acerca De La Propuesta

De La Justicia Restaurativa

Edson Luiz André de Sousa \&

Márcia Barcellos Alves Züge

Universidade Federal do Rio Grande do Sul

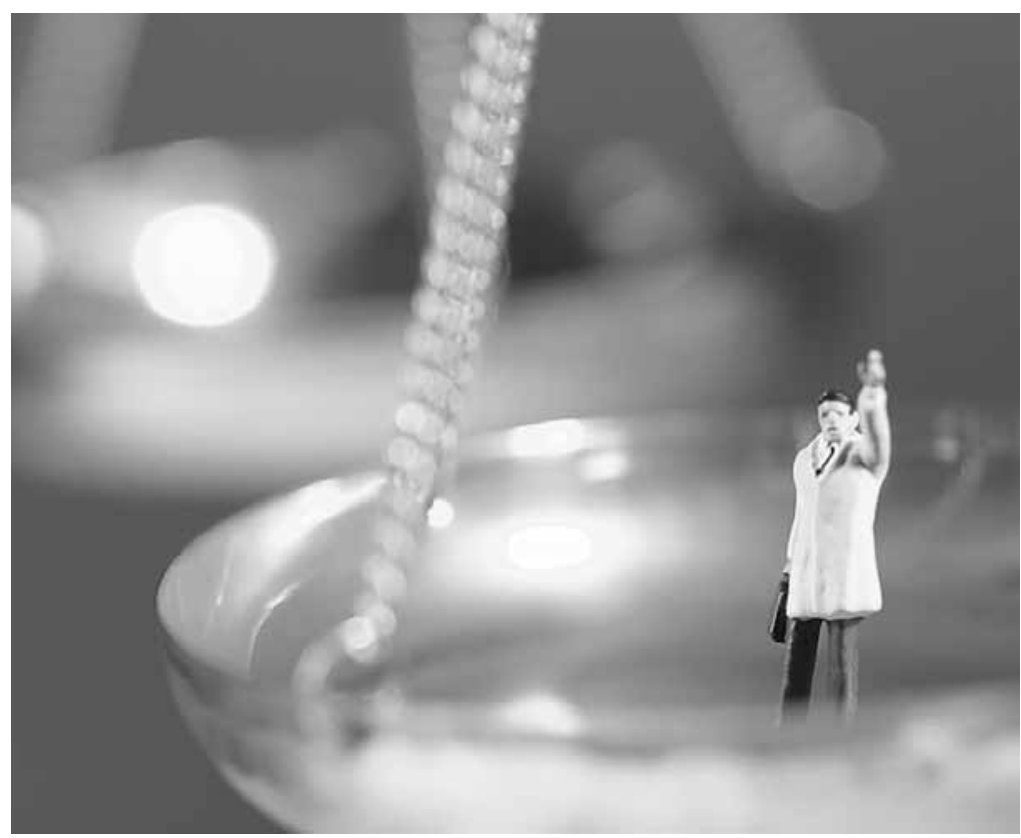


Um dos

fenômenos mais inquietantes da história do espirito humano é esquivar-se do concreto.

Possuímos uma acentuada tendência a nos lançarmos sempre ao longínquo, indo constantemente de encontro a tudo aquilo que, estando imediatamente à nossa frente, deixamos de ver.

Elias Canetti (A Consciência das Palavras)

Resumo: Partindo da constatação da necessidade de alternativas ao sistema de Justiça atual, o presente artigo objetiva dar voz a uma das propostas que vem ganhando força no cenário jurídico mundial: a Justiça Restaurativa. Para tanto, este artigo explora essa proposta, promovendo uma análise crítica amparada em autores da psicanálise (freudo-lacaniana) e da Filosofia (com F. Ost e J. Derrida). Através da Justiça Restaurativa, é possível questionar a potência da circulação da palavra, característica que promove o tensionamento entre psicanálise e Direito. Além disso, a questão da Lei e das leis, da performatividade dos atos da fala, da posição do Juiz, da experiência do encontro restaurativo e da função das utopias são os principais vieses que compõem esta análise. Mais voltado para a possibilidade de anunciar questionamentos sobre essa proposta tão nova no contexto brasileiro do que de encontrar respostas satisfatórias, este artigo mantém em suspenso várias conclusões, embora assuma a constatação da importante função utópica da Justiça Restaurativa.

Palavras-chave: Direito Penal. Psicanálise e direito. Filosofia. Justiça.

Abstract: Starting from the need of finding alternatives to the current justice system, the following article seeks to give voice to one of the proposals which has been gaining strength worldwide in the legal scenario: the Restorative Justice. Thus, this article explores this proposal by promoting a critical analysis based on authors of psychoanalysis (freudian - lacanian) as well as authors of Philosophy (F. Ost and J. Derrida). Through the Restorative Justice it is possible to question the power of the word flow which is a characteristic that promotes the tension between psychoanalysis and Law. Moreover, the issues of "Law" and "Laws", the performativity of the capacity of speech, the position of the judge, the experience of the restorative encounter and the function of utopias are the main ideas that are part of this analysis. More focused on the possibility of announcing questions about such new proposal in the Brazilian context than finding satisfactory answers, the article places several conclusions on hold, however assuming the important utopian function of the Restorative Justice.

Keywords: Criminal Law. Psychoanalysis and law. Philosophy. Justice.

Resumen: Partiendo de la constatación de la necesidad de alternativas al sistema de justicia actual, el presente artículo tiene como objetivo dar fuerza a una de las propuestas que ha ganado poder en el escenario jurídico mundial: la Justicia Restaurativa. Para tanto, este artículo explora la propuesta de la Justicia Restaurativa, promoviendo un análisis crítico amparado en autores de la Psicoanálisis (freudo-lacaniana) y de la Filosofía (con F. Ost y J. Derrida). A través de la Justicia Restaurativa es posible cuestionar la potencia de la circulación de la palabra, característica que promueve la tensión entre Psicoanálisis y Derecho. Además de eso, la cuestión de la "Ley" y de las "Leyes", de la "performatividad" de los actos del habla, de la posición del Juez, de la experiencia del encuentro restaurativo y de la función de las utopías son las principales tendencias que componen este análisis. Destinado más a la posibilidad de anunciar cuestionamientos acerca de esa propuesta tan nueva en el contexto brasileño que a encontrar respuestas satisfactorias, este artículo mantiene en suspenso varias conclusiones, aunque asuma la constatación de la importante función utópica de la Justicia Restaurativa.

Palabras clave: Derecho criminal. Psicoanálisis y derecho. Filosofía. Justicia.

Abordar o tema da Justiça Restaurativa é apostar em uma outra perspectiva de avaliar a forma que até o momento encontramos de fazer justiça. O sistema jurídico atual vem enfrentando fortes impasses. Há muito, tal sistema vem revelando suas impossibilidades, suas fragilidades e seus limites. São muitos os autores do Direito que explicitam a falência do sistema jurídico tal como ele é tomado hoje (Pinto, 2006; Rolim, 2006; Sica, 2007). Como em quase toda falência, uma série de fatores se coaduna para compor esse cenário: a precariedade total do sistema penitenciário talvez seja a pior e a mais grave, mas esconde outras, como, por exemplo, a posição do Juiz, a fragilidade dos códigos penais, etc.
Em função disso, algumas práticas alternativas vêm ganhando força no cenário jurídico mundial. Uma delas é a Justiça Restaurativa $(J R)$, prática já difundida em muitos países, que vem dar voz às partes envolvidas no processo legal, questionar o monopólio estatal da Justiça criminal, o uso dogmático do Direito penal positivo, propondo um conceito mais amplo de crime e de suas consequências, com foco na restauração. Para tanto, propõe um ritual mais informal, no qual vítima e agressor são postos em diálogo mediado e, a partir de seus testemunhos, vislumbram possibilidades de restauração das repercussões do ato infracional. 
1 Salientamos que a escolha pelo recorte apresentado neste artigo é fruto de indicações importantes realizadas pela banca examinadora da dissertação, composta pelos professores Beatriz G. Aguinsky, Jorge Broide, Maria Cristina Poli e Paulo Endo.
No Brasil, três projetos-piloto vêm sendo desenvolvidos e testados, e revelam bastante sucesso: em Porto Alegre - RS, no âmbito da Justiça infanto-juvenil, em São Caetano do Sul - SP, em escolas, e em Brasília - DF, voltado este último para infratores adultos, em trabalho com crimes de menor potencial ofensivo e contravenções penais. O projeto de lei que prevê o recurso da Justiça Restaurativa no Brasil ainda está em trâmite legal, por isso, as experiências ainda são tão incipientes e se resumem às experimentações dos projetos-piloto e às discussões e pesquisas acadêmicas.

Dessa forma, a proposta deste artigo é apresentar e discutir alguns dos principais preceitos da Justiça Restaurativa. Na realidade, este texto surge de uma pesquisa mais ampla, realizada no percurso de mestrado em Psicologia Social e Institucional da UFRGS ${ }^{1}$.

Vale destacar que o presente artigo não tem o objetivo de defender tal proposta, tampouco de sublinhar somente suas fragilidades e limitações. Nossa posição não é a do advogado de defesa, nem o de acusação; muito menos a de juiz. Tal como a Justiça Restaurativa propõe, nosso objetivo também é o de pôr a palavra em circulação, buscando muito mais as perguntas que podem ser formuladas para se pensar criticamente a proposta do que propriamente as respostas a ela.

Além disso, temos o objetivo de tensionar a fecunda aproximação entre psicanálise e Direito. Tal aproximação não se configura como uma novidade no cenário acadêmico. Muitas pesquisas vêm revelando tanto as evidências das possibilidades de articulações (por vezes, surpreendentes) quanto importantes dificuldades nesse diálogo. No contexto psicanalítico, as diferenças entre os dois campos fizeram com que a aproximação entre psicanálise e Direito fosse frequentemente malvista e mal-entendida, ao passo que, no contexto do Direito, na maioria das vezes, continuasse sendo desconhecida.

\section{Sobre a Justiça restaurativa: explanação e derivações}

Um gigantesco bloco de pedra cinza chama a atenção em plena Praça da Matriz, no centro da capital Porto Alegre. Cinza, gélida e séria, a imperiosa construção do Palácio da Justiça representa também pomposidade, poderio e maestria.

Durante mais ou menos 50 anos, o edifícioedificação podia ser assim caracterizado. Há quatro anos, porém, o grande muro cinza ganhou um enfeite (ou seria um em-feito?): uma grande escultura, com nove metros, feita de bronze - projetada e executada por Carlos M. Fayet e Luis F. Corona.

A escultura fez com que o prédio chamasse ainda mais atenção, não só pela beleza do enfeito, mas principalmente pelo que ele denuncia: a Deusa Themis, Deusa da Justiça, não é mais a mesma.

Uma Deusa diferente, porém inconfundível, reina absoluta no Palácio da Justiça. Ela não tem mais vendas; Themis não é mais cega, agora ela consegue enxergar: o que ela vê? As vendas da Deusa que, na visão de muitos, representavam a neutralidade do sistema jurídico (que não julga, apenas aplica as leis) não estão mais lá.

A Deusa tem também cabelos de guerreira, cabelos esvoaçantes. A intimidade de um de seus seios está à mostra. Seus pés e suas mãos são salientes em tamanho. Também a balança que a caracterizava não está mais lá em seus braços; Themis traz consigo, agora, a capacidade de uma espada e a sabedoria de um livro (onde se lê, em letras trêmulas, LEGES).

A Deusa do Palácio da Justiça de Porto Alegre denuncia a potência interrogativa da arte.

Arte cria-ação. Arte-fato.

Fragmento de um diário; escrito em junho de 2009 
2 Na literatura sobre Justiça Restaurativa, é bastante frequente a utilização da sigla JR para designá-la. Aqui, também essa abreviação será, por vezes, utilizada.

3 Os membros da população Maori eram discriminados em relação aos brancos de origem europeia. Havia um grande número de adolescentes nativos em regime de internato.
De acordo com Zehr (2008), um dos principais teóricos no âmbito da Justiça Restaurativa, foi em 1977 que Albert Eglash utilizou pela primeira vez essa denominação $(J R)^{2}$ para diferenciar três possibilidades de respostas ao crime, que seriam: a Justiça Retributiva, baseada na punição, até hoje amplamente difundida, uma segunda possibilidade, focada na reeducação, chamada Justiça Distributiva, e, por fim, a Justiça Restaurativa, cujo elemento fundamental seria a reparação.

Nesse momento, a tentativa de Eglash era reformular o conceito de restituição criativa, que consistia na reabilitação técnica do ofensor, o qual, sob orientação apropriada, era auxiliado a encontrar formas de pedir perdão ao ofendido. Todavia, segundo Pinto (2006), tal conceito ainda estava bastante distante dos princípios da Justiça Restaurativa atual, principalmente por conceder pouca atenção à vítima e por se limitar à reintegração material das consequências.

Ao contrário do que, em um primeiro momento, poderíamos pensar, os preceitos da Justiça Restaurativa não são uma novidade dentro das práticas e concepções jurídicas. Em algumas comunidades nativas, inclusive, já era possível vislumbrar alguns dos seus mais importantes princípios. Como lembra Rolim, trata-se de práticas muito antigas e presentes na tradição de muitos povos:

Princípios restaurativos teriam mesmo caracterizado os procedimentos de justiça comunitária durante séculos. Essas tradições foram sobrepujadas pelo modelo de Justiça criminal tal como conhecemos hoje em praticamente todas as nações modernas, o que torna especialmente difícil imaginar a transposição de seu paradigma (2006, p. 236)

De acordo com Ferreira (2006), o paradigma punitivo (retributivo) só preponderou nos três últimos séculos. Foi a partir dos séculos XI e XII, com a assunção da Igreja Católica, que tem início a transição das práticas restaurativas e da justiça comunitária para o sistema de Justiça Retributiva. Tal sistema consolidou-se a tal ponto que, em meados do século XIX, já era concebido como o único sistema aceitável.

No final do mesmo século, motivado pela constatação das fragilidades do sistema retributivo, o modelo restaurativo tornase alvo de novas pesquisas. No século XX, passa a ser comumente aplicado a conflitos comerciais, étnicos, a impasses familiares, penais, ambientais e de consumo.

Nos anos 80, a prática de mediação vítimaagressor assume lugar destacado, e, nos anos seguintes, começa a ser utilizada em larga escala. Inicialmente, o interesse era por um modelo menos repressivo e menos punitivo na reeducação de jovens agressores; logo em seguida, as práticas restaurativas passaram a ser aplicadas também aos adultos.

Dessas considerações, é possível extrair uma primeira pergunta: que condições foram necessárias para que a proposta da JR pudesse ser resgatada como uma possibilidade de fazer justiça? Mantenhamo-la em suspenso.

Segundo Sica (2007), o primeiro país a implantar as práticas restaurativas foi a Nova Zelândia. Em 1989, foi aprovada uma lei sobre crianças, jovens e suas famílias (denominada Children, Young Persons and their Families' Act) e assim surgiram as chamadas reuniões de restauração, com influência direta das reuniões Whanau, dos aborígines Maori ${ }^{3}$.

Com a aprovação da lei de 1989, o tradicional processo através dos tribunais foi substituído por maior poder de decisão da família acerca de que sanção seria mais adequada ao infrator. A polícia e os serviços de proteção auxiliavam as famílias nesse processo.

Devido à semelhança na forma de procedimento, fica evidente a influência 
desses processos no movimento restaurativo. Todavia, a Justiça Restaurativa certamente tem outras raízes além das práticas aborígines. Todas as transformações estruturais que foram acontecendo, tanto dentro quanto fora do campo penal, foram igualmente importantes e decisivas no desenvolvimento do movimento restaurativo.

Dessa forma, na década de 70, tem início esse movimento jurídico que fica conhecido como restaurativo e que vem criticar o monopólio estatal da Justiça criminal, o poder de decisão colocado nas mãos de alguns atores jurídicos (juiz e/ou representantes jurídicos do Estado), o uso dogmático do Direito penal positivo e o foco no infrator (que deve ser punido), entre outros posicionamentos que foram sendo tomados pela chamada Justiça Retributiva.

Segundo Zehr (2008), os esforços da Justiça Restaurativa se dão no sentido de se ter um conceito amplo de crime, podendo-se entendê-lo como um ato que afeta não só a vítima mas também o próprio autor do crime e a comunidade, através de uma variedade de danos. Há uma primazia pelo interesse das pessoas envolvidas e da comunidade, como uma Justiça criminal participativa. Promove-se a responsabilidade pela restauração no âmbito social, compartilhada coletivamente e voltada para o futuro. Utiliza-se uma forma crítica e alternativa do Direito, flexível culturalmente e que tem na persuasão (e não na dissuasão) sua base.

A Justiça Retributiva tradicional, ao contrário, tem um conceito estritamente jurídico de crime (violação da lei). Há um primado pelo interesse público, um monopólio estatal da Justiça criminal; a culpabilidade é individual e voltada para o passado (pagar pelo que fez), e representa o uso dogmático do Direito penal positivo. O Estado mostra-se indiferente quanto às necessidades do infrator, da vítima e da comunidade afetada, como se o ato infracional não fizesse parte de um contexto de história.
Com relação aos procedimentos, a Justiça Restaurativa estabelece um ritual informal e comunitário com os envolvidos, estritamente voluntário e colaborativo, e agencia um processo decisório compartilhado com as pessoas envolvidas (multidimensionalidade). É essencial que fique claro para todos os participantes dos encontros que tudo o que ali se passa deve ter um caráter de confidencialidade, isto é, que se comprometam com o sigilo. Além disso, deve ficar claro que o processo restaurativo é complementar, e não excludente ao retributivo, isto é, devese salientar que, atualmente, a proposta do modelo restaurativo não é a de substituir o procedimento retributivo, mas de trabalhar junto a ele.

O modelo retributivo, por sua vez, utiliza-se de um ritual solene e público, contencioso e muitas vezes questionável do ponto de vista argumentativo, uma vez que cada parte promove sua defesa ou acusação, isto é, cada parte expõe a sua verdade, mas somente uma (em muitos casos, tão somente aquela melhor articulada argumentativamente) é aceita como legítima. A linguagem, as normas e os procedimentos são formais, complexos e funcionam como garantias; as autoridades e os profissionais do Direito são seus representantes, e o processo decisório fica nas mãos dessas autoridades.

Quanto aos resultados, ainda segundo Zehr (2008), a Justiça Restaurativa tem uma abordagem tanto do crime quando de suas consequências, com um foco na restauração e na relação entre as partes. Vislumbra, através disso, as reparações material, moral e emocional, que resultam na responsabilização espontânea por parte do infrator. Além disso, visa à proporcionalidade e à razoabilidade das obrigações assumidas no acordo restaurativo.

A vítima ocupa o centro do processo, com voz ativa. O infrator, por sua vez, é visto no seu potencial de responsabilizar-se por seus danos 
4 Essas expressões (sujeito do Direito e sujeito do desejo) fazem referência a dois livros organizados por Sônia Altoé e aos artigos que os compõem: Altoé, S. (2004), (Org.), Sujeito do Direito, Sujeito do Desejo Direito e Psicanálise (2a ed.). Rio de Janeiro: Revinter, e Altoé, S., (2007). A Lei e as Leis Direito e Psicanálise. Rio de Janeiro: Revinter, e também participa ativamente do processo, interagindo com a vítima e a comunidade. Esse ponto parece especialmente convocatório no que tange ao olhar que a psicanálise oferece, na medida em que deixa evidente a inclusão do aspecto de sujeito psíquico no processo. Retornaremos a essa questão mais adiante.

Segundo Pinto (2006), enquanto a Justiça convencional diz "você fez isso e tem que ser castigado!", a Restaurativa pergunta: "o que você ainda pode fazer para restaurar o prejuízo que trouxe?"

Dessa forma, a Justiça Restaurativa empreende um esforço na conciliação entre as partes: vítima e agressor são postos em diálogo (mediado) e têm, através dos seus testemunhos, a possibilidade de - tendo em vista a irreversibilidade dos fatos - pensar em meios de restaurar os efeitos do dano. Outros membros da sociedade, afetados pelo crime como sujeitos centrais, também têm a possibilidade de participar da busca por soluções reparativas.

Além disso, vale salientar que as práticas restaurativas são aplicáveis a qualquer tipo de conflito - família, vizinhança, escola, trabalho. No contexto da Justiça, porém, são aplicadas no campo da Justiça criminal, principalmente com infratores adultos.

Como modalidade jurídica, abandona a concepção meramente vingativa da vítima para com o infrator e acredita que, através da escuta dos testemunhos de ambas as partes, são possíveis possibilidades mais autênticas de justiça.

Assim, conforme referido, na Justiça Restaurativa, as partes ganham voz no processo, assumindo uma posição ativa, ao contrário do que ocorre no modelo jurídico atual. Com essa observação, é possível dar contorno a algumas perguntas: qual a função do testemunho na Justiça
Restaurativa? Como a palavra circulante pode fazer a diferença em um processo de Justiça? Nesse caso, a psicanálise pode ter função, como instrumento, para avaliar a potência da palavra? Qual a potência da fala? Que vertigens ela é capaz de promover?

\section{A potência da palavra: psicanálise, Direito... e Filosofia}

Como lembra Guyomard (2004), quando um sujeito, em análise, se põe a falar, ele abre espaço para que significantes e fantasias possam emergir. A partir deles, a análise se desenrola em referência a uma verdade, que não diz respeito à realidade histórica em si. Dessa realidade, a verdade do sujeito revelase, sobretudo nos limites e nas lacunas, menos tributária dos acontecimentos do que das determinações simbólicas.

Ao se falar em verdade, Direito e psicanálise tomam formas absolutamente incongruentes, demonstrando uma de suas diferenças mais essenciais. Enquanto a psicanálise se debruça na verdade do sujeito, na verdade inconsciente, singular, na verdade do desejo, isto é, em uma verdade, o Direito se move em busca $d A$ verdade, da verdade única, que se faça valer a todos.

Talvez seja possível dizer, porém, que o Direito vem descobrindo os impasses desse pré-suposto. Seria a Justiça Restaurativa um esforço no sentido de considerar a verdade do sujeito no processo jurídico? É possível pensar em outras formas de fazer justiça? É possível que o sistema jurídico leve em consideração outras concepções de verdade e, ainda assim, consiga operar como instituição?

Pensar nas diferenças e nas aproximações que o sujeito do Direito e o sujeito do desejo (através da psicanálise) podem revelar significa pensar nos conceitos que alguns autores denominam a Lei e as leis ${ }^{4}$. 
Guyomard (2007) é um dos autores que se propõem a interrogar tal interlocução. $\mathrm{O}$ autor afirma que, de um lado, estão às leis, com toda a complexidade, errância e carência que podemos constatar nos códigos escritos; de outro lado, todavia, está a Lei, o que Guyomard (2007) lembra que Lacan chama de lei da linguagem, de lei simbólica. Vale destacar que a Lei, em seus múltiplos aspectos, coloca-se como lei da filiação, que está ali para assegurar a questão da identidade.

A tensão entre a Lei e as leis, segundo o mesmo autor, sempre esteve no cerne das preocupações freudianas, e isso se deve a uma simples razão: se a psicanálise não é normativa e, portanto, não está a serviço do poder, das instituições, então ela relativiza as leis. Ao contrário de entender a saúde como adaptação às normas, a psicanálise mostra que, às vezes, essa adaptação é sinônimo de doença que custa muito caro a quem dela sofre.

Desde as suas primeiras conferências, Freud considerou que o preço pago pelo indivíduo para obedecer às normas sociais e à moral sexual representa um trabalho psíquico, uma energia que poucos podiam pagar sem ficar doentes.

Nas palavras de Guyomard:

Sem distinguir completamente o sujeito individual do sujeito social, a psicanálise aumenta profundamente a separação entre os dois, pois a lei sobre a qual ela se apóia, ou a referência à lei que ela propõe, é, como se sabe, o que ela chama de complexo de Édipo. [...] Isso faz com que o complexo de Édipo, com a questão da barreira contra o incesto, se torne, de uma maneira simples, mas na verdade muito complexa, o que a psicanálise chama de Lei. Lei, portanto, que proíbe o incesto e que proíbe o parricídio, ou seja, o assassinato do pai $(2007$, p. 6)

Para o autor, a lei nos protege, e é por isso que nós a invocamos. Ao mesmo tempo, porém, ela nos violenta, e, por isso, nós a recusamos. Há uma violência, uma tirania, nas leis.

Para pensar sobre essa questão, o Guyomard lembra que Lacan dizia que a lei não se opõe ao desejo, mas que a Lei, com L maiúsculo, no sentido simbólico, e o desejo são duas faces da mesma operação. Como exposto anteriormente, a Lei, no sentido da linguagem, institui o que a psicanálise (em Lacan) chama de desejo. Aqui, desejo não é um elemento biológico ou pulsional, e sim, o efeito da linguagem sobre o sujeito e, ainda, a inscrição do sujeito na linguagem. O desejo nasce da e com a linguagem. É pelo fato de falarmos, pelo fato de não podermos nos impedir de falar e até de falar conosco mesmos, "pelo fato de que 'isso fala' em nós" (2007, p. 29) e pelo fato de que nossa identidade está desde sempre vinculada à linguagem e aos outros que a dimensão do desejo nasce e que um certo número de interditos fundam a comunidade humana. A partir do momento em que o sujeito fala, ele já está marcado pela Lei, pela lei da linguagem.

Como se pode perceber, a psicanálise confere uma importância fundamental, constitutiva, à linguagem. É através da palavra que ela produz efeitos. Quanto às questões clínicas, a psicanálise propõe uma forma singular de trabalho que admite extrema relevância ao que vai além da história contada: propõe que se opere com significantes e que se atente para o lugar da enunciação, abrindo espaço para a condição de insuficiência, do saber mais e questionando a passagem entre intenção e expressão, já que nossa obra fundamental, o sintoma, carrega nossas intenções, das quais sabemos muito pouco.

Nesse sentido, podemos pensar no sujeito barrado (\$) proposto por Lacan (1998), nessa desarmonia constitutiva da ilusão entre intenção e expressão, na tentativa imaginária de uma articulação exata entre pensar- 
sentir-falar-fazer. A narração descobre aí sua pobreza, referendando Walter Benjamin (1994). A imperiosa diferença entre sensação vivida e sensação narrada só mostra suas dimensões no efeito que produz no outro.

Endo (2008) também contribui com o tema (atentando, principalmente, na sua função com relação/oposição às catástrofes). Nas palavras do autor:

Chegamos ao ponto em que a psicanálise é convocada, ao ponto em que a necessidade e o desejo em testemunhar se inscrevem numa insistência em direção à própria dor, ao próprio sofrimento e à impossibilidade de se desfazer dessas experiências como alheias e impróprias. Reconhecer-se no próprio dizer como se, no próprio ato de fala, conjuminassem ação e discurso, corpo e linguagem e o sujeito do testemunho se expusesse ao próprio descentramento, ao próprio desconhecimento e à própria negação de uma temporalidade cronológica e crônica, própria à história, aos fatos e à objetividade. O descentramento então, como possibilidade privilegiada onde a dor se corporifica, revelando-se em sua formação mais primitiva, um quase-corpo. Será desse ponto que o sujeito pode nascer no a posteriori da morte invocada pelo golpe da violência excessiva e do emudecimento, onde se banham as pulsões de destruição mudas e imperativas. (s.p.)

O autor ressalta o "lugar infame da objetividade" quando da urgência de reconhecer-se no que se diz, quando se restitui à fala a propriedade sequestrada pela ambição do consenso e da última versão dos fatos. "Aqui é preciso observar no que tange aos testemunhos: não há última, nem final versão dos fatos" (2008, s.p ), diz o autor.

Para Endo (2008), o testemunho está no seio do fazer analítico, pois o inconsciente fala através da escuta alheia. O autor cita Didier Anzieu, na seguinte frase: "não há auto-análise séria se ela não for falada a alguém". E cita também Shoshana Felman, que evidencia sua concordância na frase "são precisos - ao menos [inclui Endo] - dois para testemunhar o inconsciente" (2008, p. 73).
Para o autor, o estatuto diferido da montagem inconsciente não tem como ser previamente anunciado a não ser em pleno curso alteritário, no exercício da fala e da escuta imersas no campo da associação livre e flutuante. Muitos dos elementos livres e flutuantes suspensos no espaço analítico, ressalta o autor, são natimortos, e um dos principais ofícios do psicanalista é reconhecer, a posteriori, no que se faz fala em análise, as partes mortas, a pulsão de morte. Esse reconhecimento consiste em distinguir a fala e o discurso na repetição que, insistentemente, intenta matar toda significação e todo sentido. "Não se trata, pois da constrição da fala explicativa, mas da expressão da fala turva, que abdica da autoridade do dizer explicativo rumo à singularidade suposta no dizível, que ainda resiste à representabilidade" (2008, s.p.). O testemunho revela-se, então, a aposta no lugar equívoco da escuta.

No que tange ao Direito, uma das referências à palavra pode ser pensada através do que Derrida (2007) chama de performatividade, a estrutura performativa dos atos da fala, isto é, o enunciado performativo como aquele que acarreta seu próprio conteúdo proposicional, que cria um novo fato social no mundo por ser enunciado em um contexto social específico. Os enunciados performativos têm a potência de um verdadeiro ato. Pode-se dizer que a palavra performática é, em si, um ato (e em transferência, um ato analítico).

No Direito, isso pode ser pensado através da tão comum e curiosa situação de um Juiz (de paz) que declara um homem e uma mulher, respectivamente, marido e esposa, e, a partir daquele exato momento, eles passam a sê-lo. Como isso acontece?! Uma palavra que, proferida por aquele investido simbolicamente para tal, transforma o estatuto da pessoa, como ser social e também como sujeito. 
Com relação à performatividade, ou à magia performativa, sustentada por Derrida, o autor diz :

O próprio surgimento da Justiça e do Direito, o momento instituidor, fundador e justificante do Direito, implica uma força performativa, isto é, sempre uma força interpretadora e um apelo à crença: desta vez, não no sentido de que o Direito estaria a serviço da força, instrumento servil, dócil e portanto exterior do poder dominante, mas no sentido de que ele manteria, com aquilo que chamamos de força, poder ou violência, uma relação mais interna e mais complexa. [...] Ora, a operação de fundar, inaugurar, justificar o Direito, fazer a lei, consistiria num golpe de força, numa violência performativa e portanto interpretativa, que, nela mesma, não é justa nem injusta, e que nenhuma justiça, nenhum direito prévio e anteriormente fundador, nenhuma fundação preexistente por definição poderia nem garantir nem contradizer ou invalidar. Nenhum discurso justificador pode, nem deve, assegurar o papel de metalinguagem com relação à performatividade da linguagem instituinte ou à sua interpretação dominante (2007, p. 24)

Dessa forma, para Derrida, a Justiça não é, necessariamente, sinônimo de Direito ou lei, e a tentativa de se tornar justiça como Direito precisa de força, precisa recorrer à força desde o seu primeiro instante. "Não há direito sem força" (2007, p. 08), diz o autor.

Para Derrida, nós não obedecemos às leis porque elas são justas (já que elas, em si, não são justas), e sim, porque têm autoridade. Essa autoridade reside tão somente no crédito que nós lhes oferecemos. Tal crédito justifica a alusão que Derrida faz ao caráter místico da autoridade. Nas palavras do autor: “Nelas (nas leis) acreditamos, eis o seu único fundamento" (2007, p. 21).

Por essa via, tais apontamentos nos fazem questionar a posição do Juiz na JR. Um dos seus esforços, conforme já exposto, é o de dissipar o poder de decisão do Juiz, fazendo com que as partes participem ativamente do processo. A Justiça Restaurativa retira o Juiz de cena ou propõe que ele ocupe uma outra função?

François Ost é um dos mais importantes autores no cenário da Filosofia do Direito. As questões sublinhadas pelo jurista e filósofo belga sobre o funcionamento jurídico também perpassam a análise da psicanálise. No texto Júpiter, Hércules e Hermes - os Três Modelos de Juiz (1993), por exemplo, o autor questiona as diferentes posições que o Juiz pode tomar, isto é, questiona de que lugar o Juiz fala.

Ost (1993) descreve, então, três modelos de Juízes, três possibilidades de posições. O primeiro modelo que o autor descreve é o do Juiz Júpiter. Júpiter é um Juiz que adota o modelo de Direito codificado, linear e unidirecional, com um escalonamento de regras hierarquicamente derivadas. Ele acredita na completude da lei, na plenitude do ordenamento jurídico, nos códigos que tudo preveem e tudo resolvem. É um Juiz dogmático, positivista, que entende que as regras são as únicas detentoras de força cogente.

O segundo modelo de Juiz que Ost (1993) revela é o Juiz Hércules. Esse modelo identifica o Direito como meio de conquista da paz social; é o modelo que mais se aproxima da common law e da sociological jurisprudence, nos quais não só as regras mas também os princípios são valorizados. O Direito é equivalente ao Direito jurisprudencial; não é a lei que cria a autoridade, mas a decisão. Aqui, a aplicação das normas em um dado caso se sobressai à generalidade e à abstração da lei.

Assim, ao contrário do Juiz Júpiter, homem de lei, que coloca as regras no centro do sistema e acredita que pode deduzir mecanicamente decisões particulares a partir desse sistema, o Juiz Hércules, engenheiro social, entende 
que a decisão judicial é o mais importante do sistema. Parte-se, assim, de um modelo piramidal para o modelo de funil, em que da evocação genérica surge a limitação ao caso concreto.

Oterceiro modelo de Juiz, segundo Ost (1993), é o Juiz Hermes. Esse tipo de Juiz está sempre em movimento, assegura o preenchimento das lacunas, conecta povos afastados, medeia conflitos e arbitra interesses, na forma de uma rede constantemente conectada e em interrelação, tendo por base não mais os códigos ou os processos, mas um banco de dados para a criação normativa da jurisprudência, dos costumes, das convenções internacionais, dos princípios gerais do Direito, etc. O desafio, aqui, é passar da monofonia para a polissemia, sem cair na cacofonia (no ruído carente de significado).

Se Júpiter insiste no polo da convenção e Hércules no da invenção, Hermes, por sua vez, respeita o caráter hermenêutico e reflexivo do juízo jurídico, que não se reduz nem a uma improvisação, nem tampouco à determinação de uma regra superior.

Através dos três modelos de Juiz, Ost (1993) demonstra que um Juiz pode ocupar uma variedade de posições. Podemos pensar que são possibilidades infinitas, e não somente três. Em que tipo de Juiz a JR acredita? Será possível pensar em uma operação restaurativa ancorada em Juízes Júpiter? Será possível manter uma engrenagem institucional tão delicada como a jurídica somente com Juízes Hércules? O que a JR deseja são Juízes Hermes?

Sem ter a intenção de responder a tais perguntas (satisfeitos com a possibilidade de anunciá-las, como já dito), podemos também pensar sobre a definição que a Juíza francesa Cazoux-Charles encontra para sua função:

Um Juiz que 'ocupa o seu lugar' é, na minha opinião, um Juiz convicto de que a lei deve ser entendida como emanação contemporânea e laica do interdito fundador de toda sociedade (interdito de assassinato e de incesto), cuja mediação e interpretação Ihe cabem. Se ele não reconhecer sua própria submissão a esse princípio, não me parece possível que transmita, por sua vez, o sentido da interdição, isto é, a necessidade, para cada ser humano, de renunciar a ser a criança de seus pais e de ceder seu lugar. Como se pode notar, posiciono-me em oposição aos que pregaram o desejo contra a lei, a liberdade contra o direito, a civilização pela morte do Juiz (2007, p.113)

Dessa forma, podemos pensar sobre a questão do Juiz no cenário que a JR propõe. Nos passos da Juíza supracitada (que não se refere à JR), podemos tomar a ideia da falta do Juiz como um aspecto muito menos potente do que se supunha, afinal, não há como negar que precisamos da lei, que precisamos da força da nominação.

Ao que parece, a JR vem se esforçando para se situar nessa e em outras fronteiras. Encontrar, aliás, esse espaço que se mantenha e se sustente entre o apoio e a punição, entre o absolutismo e a permissividade, entre a palavra e sua ausência, não é tarefa simples. Como a JR se situa nessa fronteira? Como opera como instituição? De que lugar empreende seus esforços, sua prática? Estar entre pode parecer um bom lugar, um lugar ideal, porém corre-se o perigoso risco de, em não se estando nem lá nem cá, não se estar em lugar nenhum. Os autores da área certamente acreditam que esse lugar não só é possível como exista.

Para Aguinsky e Capitão, por exemplo, os achados teóricos da Justiça Restaurativa se coadunam com "possibilidades de respostas humanizadoras às contradições entre punição e tratamento" (2008, p. 262). Possibilidades concretas de participação individual e social, de democratização do atendimento, de acesso aos direitos, de igualdade nos espaços de diálogo, de respeito e de segurança nesses mesmos espaços e de valorização 
das diferenças - através da consideração dos danos, dos responsáveis por esses e dos prejudicados pela infração - são as principais preocupações da Justiça Restaurativa. Nas palavras das autoras:

[...] A Justiça Restaurativa valoriza a autonomia dos sujeitos e do diálogo entre eles. Cria espaços protegidos para a auto-expressão e o protagonismo de cada um dos envolvidos e interessados - transgressor, vítima, familiares, comunidades - na busca de alternativas de responsabilização. Nessa perspectiva, podese contribuir para fortalecer o protagonismo dos sujeitos na construção de estratégias para restaurar laços de relacionamento e confiabilidade social rompidos pela infração

(2008, p. 262)

As autoras dizem que, desde 2005, algumas iniciativas de Justiça Restaurativa vêm sendo empreendidas em Porto Alegre, com adolescentes em privação de liberdade. Desde então, já é possível observar o poder que a Justiça Restaurativa revela de desacomodar o instituído, reorganizando os lugares pré-estabelecidos dos adolescentes autores de ato infracional, dos familiares e dos profissionais da rede. O lugar vertical, hierárquico e prescritivo há muito tempo ocupado pelos profissionais vem ganhando a possibilidade de ser desocupado. Aguinsky e Capitão (2008) afirmam que a Justiça Restaurativa carrega o signo da esperança de que novas possibilidades de democratização do atendimento à juventude em conflito com a lei possam ser vislumbradas, bem como a redução das violências praticadas pelo Estado em resposta à infração possa também ser efetivada.

Através de sua proposta, a JR abre possibilidades novas para a construção de uma responsabilidade mais genuína, exatamente no seio da interação com a força coercitiva do Estado. Com a intenção de reduzir os danos dessas intervenções, a proposta busca minimizar a violência de práticas institucionais e profissionais no seu âmbito mesmo de atuação. Com participação, autonomia e inclusão, é possível dar um sentido novo aos usuais procedimentos sem, no entanto, competir com eles.

Freud é um dos autores que denunciou, com impressionante propriedade, a aparente contradição que o homem impõe a si mesmo, tomando alguns caminhos como únicos, ainda que à custa de muito sofrimento. A criação do sistema jurídico e a constatação de sua atual disfuncionalidade geram a mesma problemática: constatamos a inoperância do sistema e, no entanto, continuamos a alimentá-lo.

O autor ressalta que, em toda a crítica que ele faz à civilização (que atende nossas exigências de forma tão inadequada e permite a existência e a manutenção de tanto sofrimento), está exercendo "um direito justo, e não nos mostrando inimigos da civilização" (1930, p.120). É provável que o homem efetue alterações no sistema civilizatório para que suas necessidades sejam mais bem satisfeitas, porém, segundo o autor, também precisamos nos familiarizar com a ideia de "existirem dificuldades, ligadas à natureza da civilização, que não se submeterão a qualquer tentativa de reforma" (1930, p. 120).

A partir disso, novas perguntas surgem: o sistema jurídico é uma dessas dificuldades? Até que ponto ele pode ser questionado na medida em que nenhuma proposta consegue se configurar como substitutiva (e não somente alternativa, como a Justiça Restaurativa) a ele?

E ainda: será que qualquer proposta que se declarasse igualmente absoluta não estaria, na mesma medida, destinada ao fracasso? Talvez possamos pensar que qualquer forma de absolutismo seja violenta. Primo Levi (1988), no livro É Isto um Homem?, afirma que o homem é contra qualquer tipo de infinito. 
No mesmo sentido, Sousa afirma que a função das utopias é a de resistir aos imperativos do consenso, cada vez mais impostos pelos laços sociais. Além disso, para o autor, a associação entre utopia e o impossível produziu uma desqualificação das ações que reclamam por esse princípio em nosso tempo.

\section{Pelo direito a uma utopia}

Certa feita, um acadêmico do curso de Direito, depois de uma explanação sobre diversas problemáticas e potencialidades da Justiça Restaurativa, exclamava com relação a essa proposta: "Isso é uma completa utopia! Não há como imaginar que uma proposta como essa possa funcionar. O sistema jurídico tem inúmeros problemas, não há dúvidas. Mas soluções desse tipo são, no mínimo, ingênuas. Não existe outra forma possível de fazer as coisas, minimamente, funcionarem. Para mim, o que não tem solução, solucionado está".

Dessa fala, inúmeras questões derivam: o que faz com que alguém - em plena formação e convicto dos impasses cruciais do sistema de Justiça atual - desista da tentativa de pensar em fazer algo melhor? Quais as consequências disso? Como tal descrédito na própria função, como futuro profissional, interfere na sua formação? Será que o único efeito das utopias é a passividade, o desleixo, o descrédito? E ainda: a proposta da Justiça Restaurativa é uma utopia?

Talvez possamos pensar sobre o que se entende por utopia. Geralmente, associa-se o termo utopia àquilo considerado irreal, fantástico, imaginário, ilusório, inexistente ou inalcançável. Etimologicamente, porém, temos outras indicações: topos significa lugar, e o u refere-se a negação. Assim, utopia significa um não lugar, um nenhum lugar, um fora de lugar.

Para Ernst Bloch (2005), as utopias têm, no entanto, significado diverso do senso comum. Como lembra Sousa, em seu livro $A$ Invenção da Utopia (2007), Bloch é o grande pensador das utopias do século XX: para ele, a utopia é uma das categorias filosóficas mais importantes desse século.
De acordo com Bloch (2005), as utopias significam a radical experiência de pensar o futuro na sua potência máxima, livre da repetição do presente que insiste em manter as formas instituídas. Através das utopias, é possível antever um furo no futuro que nos move em direção ao que pode ser, ao que ainda não é e por isso faz falta: falta, motor da engrenagem do desejo humano.

No mesmo sentido, Sousa afirma que a função das utopias é a de resistir aos imperativos do consenso, cada vez mais impostos pelos laços sociais. Além disso, para o autor, a associação entre utopia e o impossível produziu uma desqualificação das ações que reclamam por esse princípio em nosso tempo. Ao contrário do que se pensa, as utopias sempre foram "ficções conscientes de sua função de acionar o espírito crítico da consciência de um determinado tempo" $(2007$, p. 21).

Através das utopias, é possível promover um olhar estrangeiro ao presente, interrogando o instituído. As utopias são forças moventes e só se contentam com o movimento-pulsão que lhes é característica. Por isso, pode-se pensar que as utopias não se referem a um lugar ideal de chegada, mas que o lugar ideal das próprias utopias é o caminho até lá. Se a utopia é contra qualquer contentamento, só pode tomar como ilusão a ideia do lugar ideal, porque sempre é possível ir mais longe. A utopia carrega a potência da força dos rumores críticos, que trazem a possibilidade de sonhar com outros mundos. Cioran (1994), lembrado por Sousa (2007), afirma que só agimos sob a fascinação do impossível, e que, assim, uma sociedade incapaz de gerar utopias é uma sociedade ameaçada de esclerose e ruína.

Para Sousa (2007), a utopia tem a função de desassossegar o presente acossado pela responsabilidade com o amanhã. Trata-se de uma crítica do presente que alimenta a esperança no futuro. Ela diz do componente 
de saúde que a insatisfação com o presente e o desejo de transposição comportam. A utopia é inacabada e aberta a uma constante reinvenção. A utopia corrói os saberes instituídos e circunscreve um território em crise, uma crise que carrega a potência da fratura do presente.

\section{Considerações finais}

Depois de todo nosso percurso neste artigo, ficamos com a certeza de que a intersecção entre psicanálise e Direito, através da Justiça Restaurativa, abre-se como um campo rico de pesquisa. Encontramos a afinidade entre essas duas áreas pelo lugar singular que cada campo dá à palavra, à linguagem e ao discurso.

Como já salientamos anteriormente, nosso esforço foi realizado no sentido de enunciar algumas questões que nos pareceram fundamentais nesse diálogo. Apostamos que a Justiça Restaurativa possa revelar uma perspectiva de olhar diferente do que temos atualmente instituído sobre a forma de fazer justiça.

A certeza de que a Justiça Restaurativa ainda está longe de ser um ideal de sistema jurídico não intimida a proposta que, antes de qualquer coisa, continua a apontar um caminho possível. Através de atos possíveis como a proposta da Justiça Restaurativa é que podemos enxergar, hoje, uma Justiça diferente... a Deusa da Justiça não é mais a mesma. E isso não quer dizer que as práticas jurídicas já estejam modificadas ou transformadas: as prisões continuam superlotadas, algumas leis continuam embasando veredictos injustos, os Juízes continuam sustentando decisões frágeis, os galpões continuam abarrotados de processos.

Hoje, porém, um novo olhar surge no cenário das práticas jurídicas. A Justiça Restaurativa quebra as regras, os costumes, as formas de fazer justiça que até então se conhecia; nesse sentido, confronta uma forma de funcionamento que, há muito tempo, tem se mostrado insuficiente para dar conta dos desafios de nosso tempo.

Dentro dessa perspectiva, o resto... é resto. $\mathrm{O}$ fato de saber se a Justiça Restaurativa tem ou não uma proposta coerente, se é aplicável, em que contexto pode operar e que efeitos produz são questões consideradas, pelo viés das utopias, menos importantes do que sua força interrogante, questionadora e insistentemente inconformada com o cenário atual.

Para concluir, deixamos em aberto uma indagação feita por Ricardo Timm de Souza, em uma exposição sobre o tema. Timm afirmava que restaurativa talvez não fosse $o$ melhor termo para dizer dessa proposta ${ }^{5}$, e propõe um outro adjetivo, quiçá mais próprio: o de Justiça Instaurativa. Instaurativa de quê? Instaurativa de um espaço, instaurativa de uma abertura, instaurativa de um encontro. E, podemos acrescentar: instaurativa de uma utopia. 


\section{Edson Luiz André de Sousa}

Doutorado em Psicanálise e Psicopatologia. Mestrado em Psicanálise e Psicopatologia - Universite de Paris VII Universite Denis Diderot, professor adjunto do departamento de psicanálise e psicopatologia da Universidade Federal do Rio Grande do Sul, RS - Brasil.

E-mail: edsonlasousa@uol.com.br

\section{Márcia Barcellos Alves Züge}

Mestrado em Psicologia Social e Institucional pela Universidade Federal do Rio Grande do Sul. Psicóloga Clínica Prévôté Espaço Psicanalítico, PRÉVÔTÉ, Santa Maria, RS - Brasil.

E-mail: mbapsi@hotmail.com

\section{Endereço para envio de correspondência:}

Avenida Liberdade, 450/801. CEP: 97020-490. Santa Maria - RS.

Recebido 2/9/2010, 1a Reformulação 17/8/2011, Aprovado 26/8/2011.

Referências

Aguinsky, B. G., \& Capitão, L. C. D. (2008). Violência e socioeducação: uma interpelação ética a partir das contribuições da justiça restaurativa. Revista Katalysis, 11, 257-264.

Benjamin, W. (1994). Magia e técnica, arte e política: ensaios sobre literatura e história da cultura. (Obras Escolhidas, Vol. I, 7a ed.). São Paulo: Brasiliense.

Bloch, E. (2005). O princípio esperança (Vol. I). Rio de Janeiro: Ed. Contraponto.

Canetti, E. (1990). A consciência das palavras. São Paulo: Companhia das Letras.

Cazoux-Charles, H. (2007). O juiz da infância e da juventude - garante da ordem pública genealógica ou aprendiz de cozinheiro? In Altoé, S., A lei e as leis - direito e psicanálise. Rio de Janeiro: Revinter.

Cioran, E. (1994). Mecanismo da utopia. In História e utopia. Rio de Janeiro: Rocco.

Derrida, J. (2001, 25 de maio). A solidariedade dos seres vivos - entrevista com Jacques Derrida, por Evando Nascimento. Folha de São Paulo (Suplemento Mais).

Endo, P. C. (dez. de 2008). Partilha, testemunho e formas contemporâneas do excessivo. Revista Ide, 31(47), 70-74.

Ferreira, F. A. (2006). Justiça restaurativa: natureza, finalidades e instrumentos. Coimbra: Ed. Coimbra.

Freud, S. (1996). O mal-estar na civilização. In Edição Standard Brasileira das Obras Completas de Sigmund Freud (Vol. XXI). Rio de Janeiro: Imago. (Trabalho original publicado em 1930)
Guyomard, P. (2004). A ordem da filiação. In Altoé, S. (Org.), Sujeito do direito, sujeito do desejo - direito e psicanálise (2a ed.). Rio de Janeiro: Revinter.

Guyomard, P. (2007). A lei e as leis. In Altoé, S., A lei e as leis direito e psicanálise. Rio de Janeiro: Revinter.

Lacan, J. (1998). Subversão do Sujeito e Dialética do Desejo (1966). In J. Lacan. Escritos. Rio de Janeiro: Jorge Zahar Ed.

Levi, P. (1998). É isto um homem? Rio de Janeiro: Rocco.

Ost, F. (1993). Júpiter, Hércules e Hermes: tres modelos de juez. Doxa, Cuadernos de Filosofia del Derecho, 14, 169-194.

Pinto, R. S. G. (2006). A construção da justiça restaurativa no Brasil - o impacto no sistema de justiça criminal. Recuperado em dezembro 2008 de < http://jus2.uol.com.br/doutrina/texto. asp?id $=9878 \& p=2>$.

Rolim, M. (2006). A síndrome da rainha vermelha - policiamento e segurança pública no século XXI. Rio de Janeiro: Jorge Zahar Editor.

Sica, L. (2007). Justiça restaurativa e mediação penal - o novo modelo de justiça criminal e de gestão do crime. Rio de Janeiro: Lúmen Júris.

Sousa, E. L. A. (2007). Uma invenção da utopia. São Paulo: Lumme Ed.

Zehr, H. (2008). Trocando as lentes - um novo foco sobre o crime e a justiça/justiça restaurativa. São Paulo: Palas Athena. 